\title{
François Rouget, Pierre de Ronsard
}

\section{Dario Cecchetti}

\section{(2) OpenEdition \\ Journals}

\section{Edizione digitale}

URL: http://journals.openedition.org/studifrancesi/9824

DOI: $10.4000 /$ studifrancesi.9824

ISSN: 2421-5856

\section{Editore}

Rosenberg \& Sellier

\section{Edizione cartacea}

Data di pubblicazione: 1 octobre 2007

Paginazione: 426

ISSN: 0039-2944

\section{Notizia bibliografica digitale}

Dario Cecchetti, «François Rouget, Pierre de Ronsard», Studi Francesi [Online], 152 (LI | II) | 2007, online dal 30 novembre 2015, consultato il 09 janvier 2021. URL: http://journals.openedition.org/ studifrancesi/9824 ; DOI: https://doi.org/10.4000/studifrancesi.9824

\section{Questo documento è stato generato automaticamente il 9 janvier 2021.}

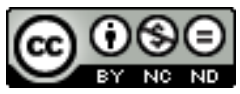

Studi Francesi è distribuita con Licenza Creative Commons Attribuzione - Non commerciale - Non opere derivate 4.0 Internazionale. 


\title{
François Rouget, Pierre de Ronsard
}

\author{
Dario Cecchetti
}

\section{NOTIZIA}

FRANÇOIS ROUGET, Pierre de Ronsard, Paris, Memini («Bibliographie des Écrivains Français», 27), 2005, pp. 527.

1 Nella validissima collana «Bibliographie des Écrivains Français» sono già comparse, per il Cinquecento, le guide consacrate a Baïf, Pontus de Tyard, Bodin, Du Bartas, La Boétie, d'Aubigné. Esce ora quella dedicata a Ronsard, che con i suoi 2901 titoli, offre una repertoriazione (quasi) completa. Strumento di ricerca utilissimo (anche nell'epoca 'internet') non solo offre l'elenco cronologico delle uscite, suddividendole per sezioni (studi generali, studi su ciascuna opera, studi tematici, ecc.), ma ne riassume sinteticamente il contenuto, indicando i mots-clés sotto cui situare ogni contributo critico, mots-clés che sono poi raccolti in un indice che favorisce la ricerca dello studioso. 